\title{
Potential biopesticides for crucifer flea beetle, Phyllotreta cruciferae (Coleoptera: Chrysomelidae) management under dryland canola production in Montana
}

\section{Authors: Briar Singh Shabeg, Frank Antwi, Govinda Srestha, and Gadi V. P. Reddy}

The final publication is available at Springer via http://dx.doi.org/10.1007/s12600-018-0645-y

Shabeg, Briar Singh, Frank Antwi, Govinda Shrestha, Anamika Sharma, and Gadi V P Reddy. "Potential biopesticides for crucifer flea beetle, Phyllotreta cruciferae (Coleoptera: Chrysomelidae) management under dryland canola production in Montana." Phytoparasitica 46, no. 2 (April 2018): 247-254. DOI: 10.1007/s12600-018-0645-y.

Made available through Montana State University's $\underline{\text { ScholarWorks }}$ scholarworks. montana.edu 


\title{
Potential biopesticides for crucifer flea beetle, Phyllotreta cruciferae (Coleoptera: Chrysomelidae) management under dryland canola production in Montana
}

\author{
Shabeg Singh Briar • Frank Antwi • \\ Govinda Shrestha • Anamika Sharma • \\ Gadi V. P. Reddy
}

Received: 16 November 2017 / Accepted: 31 January 2018/Published online: 12 February 2018

(C) Springer Science+Business Media B.V., part of Springer Nature 2018

\begin{abstract}
The crucifer flea beetle, Phyllotreta cruciferae (Goeze), is an economically important and dominant pest of canola (Brassica napus L) in the Northern Great Plains of the USA. The current flea beetle management strategy is based on using synthetic chemical treated seeds and if necessary, foliar spray of chemicals at canola seedlings in early spring for targeting adult population. However, there is an increasing demand for development of alternative management strategies for $P$. cruciferae pertaining to concerns over the development of resistance to synthetic insecticides and non-target effects on pollinators and other beneficial insects. Replicated field trials were conducted to test the efficacy of several commercially available biopesticides including Entrust ${ }^{\mathbb{B}}$ (spinosad), entomopathogenic nematode Steinernema feltiae + Barricade ${ }^{\circledR}$ (polymer gel $1 \%)$, Aza-Direct ${ }^{\circledR}$ (azadirachtin), Pyganic $1.4^{\circledR}$ EC (pyrethrin), Grandevo ${ }^{\circledR} \mathrm{SC}$ (Chromobacterium subtsugae), Venerate ${ }^{\circledR}$ XC (Heat killed Burkholderia sp. strain A396 as seed treatment and foliar application) and Gaucho ${ }^{\circledR}$ (imidacloprid) (chemical check) for the P. cruciferae management at two locations (Conrad and Sweetgrass) of Montana in 2016. Biopesticide products were evaluated based on canola leaf area injury ratings and seed yield levels. Although, there was no clear trend of
\end{abstract}

canola yield increase, selected biopesticide treatments were effective in maintaining low leaf area injury ratings as compared to untreated control. Entrust was able to maintain low leaf area injury ratings $(8.5-14.5 \%)$ when compared to untreated control (16.0-21.4\%) at both the locations. Entomopathogenic nematodes, Steinernema feltiae + Barricade $^{\circledR}$ and Venerate ${ }^{\circledR}$ applied as foliar treatments maintained significantly lower feeding injury pressure at Sweetgrass (11.8\%) and Conrad (13.4\%) locations respectively, when compared to the untreated control. Our study results suggest that these biopesticide treatment results were comparable in efficacy to the chemical seed treatment Gaucho ${ }^{\circledR}$. Other two biopesticide products- Aza-Direct ${ }^{\circledR}$ and Pyganic $1.4^{\circledR}$ EC treatments did not provide effective control of $P$. cruciferae at both the locations.

Keywords Entrust - Spinosad - Entomopathogenic nematodes (EPNs) · Steinernema feltiae $\cdot$ Barricade . Venerate

\section{Introduction}

The crucifer flea beetle, Phyllotreta cruciferae (Goeze) (Coleoptera: Chrysomelidae), is an economically important and dominant pest of canola (Brassica napus L.; Brassicales, Brassicaceae) in the Northern Great Plains of the United States and the prairies of Canada (Thomas 2003; Knodel 2017; Soroka et al. 2018). Adult flea beetles emerge from overwintering sites in spring (March-May) when the air temperature reaches $15-20^{\circ} \mathrm{C}$ (Lamb 1984). 
Adults initially feed on brassicaceous weeds, migrate to canola fields when crop emerges, and feed on young cotyledons and true leaves, and later on stems, flowers and pods (Lamb 1988; Thomas 2003). Crop damage occur further during the summer (June-August) as larvae feed on the canola seedling root hairs, and this damage can cause yield reduction of about 5\% (Thomas 2003). Annual yield losses due to $P$. cruciferae feeding are estimated to be tens of millions of U.S. Dollar in this region (Burgess 1977; Lamb and Turnock 1982; Madder and Stemeroff 1988).

Management is primarily focused in early spring when canola seedlings are most vulnerable to $P$. cruciferae injury (Thomas 2003). Currently, P. cruciferae management is based on using imidacloprid insecticide treated seeds, and further foliar application of insecticide when injury level reaches $15-20 \%$ at canola seedling stage (Lamb and Turnock 1982; Antwi et al. 2007a; Reddy et al. 2014). However, reliance on chemical insecticidebased pest management increases the risk of development of insecticide resistance (Turnock and Turnbull 1994), negative effects to pollinators and other beneficial insects. In this context, use of biopesticide product could offer an alternative treatment regimen to the conventional insecticides (Reddy et al. 2014; Knodel 2017). Biopesticides possess a unique mode of action, do minimal harm to non-target organisms, and exhibit favorable environmental and toxicological profiles (Ware 1989; Thompson et al. 2000; Sparks et al. 2001). Use of biopesticides can therefore, slow down or prevent the development of insecticide resistance (Liu and Stansly 1995; Copping and Menn 2000).

Several biopesticides are commercially available and have been explored for their potential as alternatives to conventional insecticides for the management of variety of agricultural crop insect pests (Hajek et al. 1987; Xu et al. 2010; Shrestha et al. 2015; Shrestha and Reddy 2017) including flea beetle (Antwi and Reddy 2016). Phyllotreta cruciferae management in canola, biopesticides such as entomopathogenic fungi, Beauveria bassiana (Balsamo) Vuellemin, Metarhizium brunneum (Antwi et al. 2007a, b; Reddy et al. 2014), entomopathogenic nematodes (Antwi and Reddy 2016) were found to effective in Montana. To further explore other potential biopesticides, this study aimed to test recently registered biopesticides (Pyganic 1.4 ${ }^{\circledR}$ EC, Grandevo ${ }^{\circledR}$, Venerate $^{\circledR} \mathrm{XC}$ ) along with conventional product, Gaucho $^{\circledR}$ for the management of $P$. cruciferae under field conditions in dryland farming systems in Montana.
These biopesticides were evaluated based on the flea beetle injury ratings and canola seed yield levels.

\section{Materials and methods}

Site description and field plot design

Field trials were conducted at two locations: Western Triangle Agricultural Research Center (48 ${ }^{\circ} 18.627^{\prime} \mathrm{N}$, $\left.111^{\circ} 55.402^{\prime} \mathrm{W}\right)$ in Conrad, and Sweetgrass $\left(48^{\circ}\right.$ $57.831^{\prime} \mathrm{N}, 111^{\circ} 40.801^{\prime} \mathrm{W}$ ) in the West-Central region of Montana, USA in 2016. At both locations, plots were seeded in second week of April, 2016. Canola seeds HyClass $^{\circledR}$ (WindField Solutions, LLC, Houston, Texas) were seeded at a rate of 12 seeds per $30 \mathrm{~cm}$, using a four-row plot drill with $30 \mathrm{~cm}$ row-row spacing. Weed control was done by pre-plant application of herbicide RT3 $^{\circledR}$ (a.i. glyphosate) at a rate of $2.5 \mathrm{~L} /$ ha. Fertilizers were applied at $134.5 \mathrm{~kg} / \mathrm{ha}$ of nitrogen, $25.2 \mathrm{~kg} / \mathrm{ha}$ phosphorus, $61.6 \mathrm{~kg} / \mathrm{ha}$ of potassium, and $22.4 \mathrm{~kg} / \mathrm{ha}$ of Sulphur. Both the field trials were conducted under dryland rain fed (i.e., non-irrigated) conditions. Air temperature (Fig. 1a) and precipitation data (Fig. 1b) for the period of study for Conrad and Sweetgrass were accessed from the USDA, NRCS weather station (NRCS 2016) and Alberta Agriculture and Forestry weather station (Alberta Agriculture and Forestry 2016), respectively.

The field experiments at both the locations were Randomized Complete Block Design (RCBD). Individual plots measured $3.6 \mathrm{~m} \times 1.2 \mathrm{~m}$ in size. A buffer zone of $1.2 \mathrm{~m}$ was set up between each plot to avoid cross contamination due to spray drift. Treatments were replicated 4 times at each location.

Biopesticide treatment application

Treatments used for the studies and their rates of application are presented in Table 1. Biopesticide products included in study were: Entrust ${ }^{\circledR}$ (spinosad), Steinernema-System (Steinernema feltiae) + Barricade $^{\circledR}$ polymer gel 1\%, Aza-Direct ${ }^{\circledR}$ (azadirachtin), Pyganic1. ${ }^{\circledR}$ EC, Grandevo ${ }^{\circledR}$ SC (Chromobacterium subtsugae), and Venerate ${ }^{\circledR} \mathrm{XC}$ (Heat killed Burkholderia sp. strain A396) as seed treatment and foliar application. Water served as an untreated control while the Gaucho ${ }^{\circledR}$ (imidacloprid) represented as chemical check at both study locations. A solo backpack 


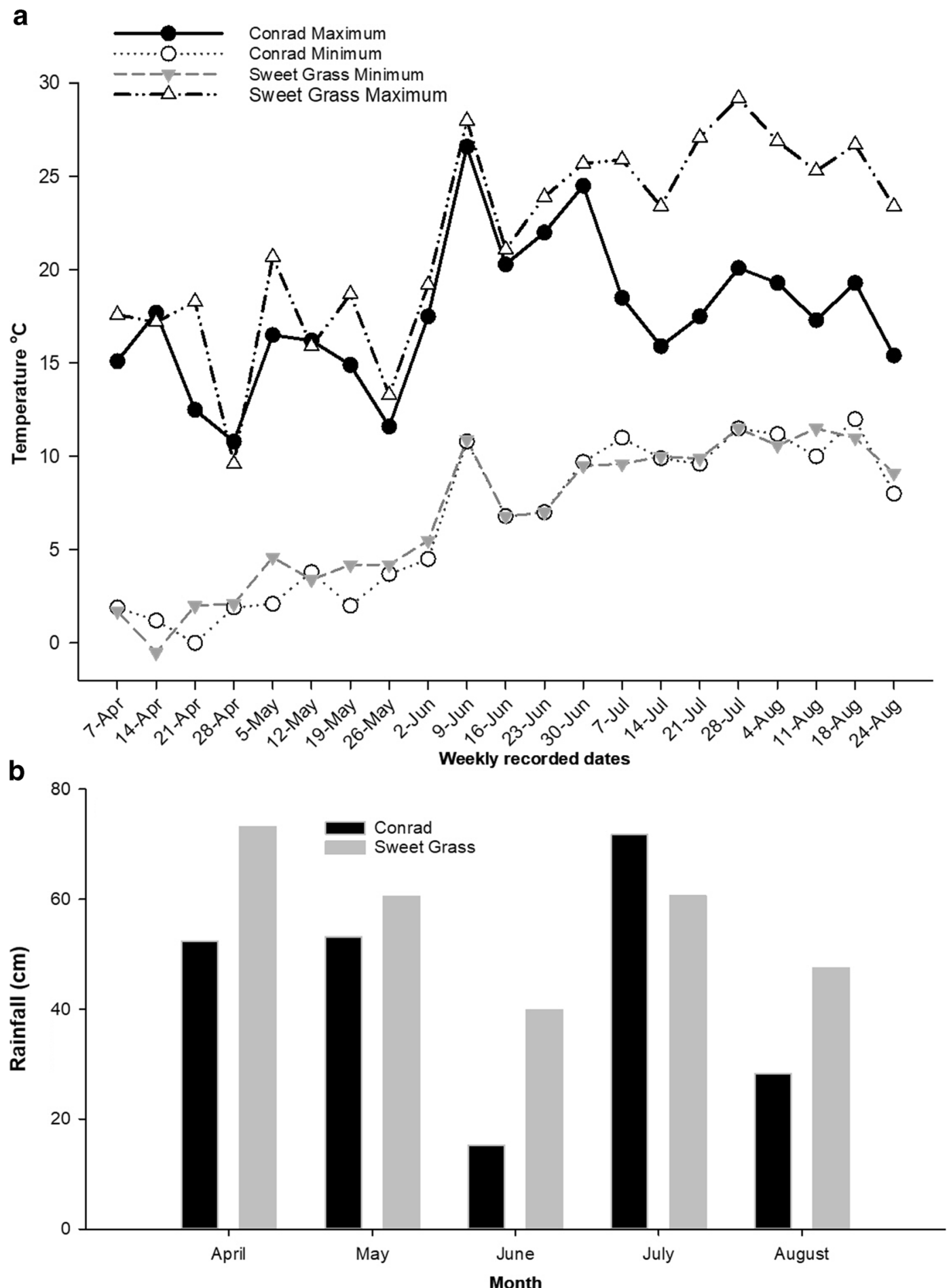

Fig. 1 a Maximum and minimum weekly mean air temperature $\left({ }^{\circ} \mathrm{C}\right)$, and b total monthly precipitation $(\mathrm{cm})$ in 2016 at $\mathrm{Conrad}$ and Sweetgrass locations

sprayer (Newport News, VA) calibrated at $816.89 \mathrm{~L} / \mathrm{ha}$ was used for treatment application, when canola was in the cotyledon or one leaf stage and after arrival of P. cruciferae in the plots. 
Table 1 Materials and rates of application in each treatment

\begin{tabular}{|c|c|c|c|c|}
\hline Treatment & Active Ingredient & Concentration & Amount/3.785 L water & Source \\
\hline Water & Water & $\begin{array}{l}\text { Same volume } \\
\text { as in mix }\end{array}$ & - & - \\
\hline $\begin{array}{l}\text { Gaucho }^{\circledR} 600 \\
\quad(\text { Seed treatment })\end{array}$ & Imidacloprid & $190 \mathrm{ml} / 45 \mathrm{~kg}$ seed & - & Bayer Crop Science, Germany \\
\hline Entrust $^{\circledR}$ & Spinosad & $\begin{array}{l}0.091 \mathrm{ml} / \mathrm{L} \text { of } \\
\text { water }\end{array}$ & $0.34352 \mathrm{ml}$ & Dow AgroSciences, IN, USA \\
\hline $\begin{array}{l}\text { Steinernema-System } \\
\quad+\text { Barricade }^{\circledR}\end{array}$ & $\begin{array}{l}\text { Steinernema } \\
\qquad \text { feltiae + Barricade } \\
\text { polymer }(1 \%)\end{array}$ & $\begin{array}{l}300,000 / \mathrm{m}^{2}+1 \% \\
\text { Barricade; }\end{array}$ & $\begin{array}{l}17.098 \mathrm{~g} \\
\quad \text { S. feltiae })+37.85 \mathrm{ml} \\
\quad(\mathrm{g}) \text { (Barricade) }\end{array}$ & $\begin{array}{l}\text { Biobest USA Inc. Romulus, MI \& } \\
\text { Barricade International (firegel.com) }\end{array}$ \\
\hline Aza-Direct ${ }^{\mathbb{R}}$ & Azadirachtin & $\begin{array}{l}1.43 \mathrm{ml} / \mathrm{L} \\
\quad(473 \mathrm{ml} / \text { acre })\end{array}$ & $5.42 \mathrm{ml}$ & Gowan Company, AZ, USA \\
\hline Pyganic1.4 ${ }^{\circledR}$ EC & Pyrethrins & $\begin{array}{l}1.45 \mathrm{ml} / \mathrm{L} \\
\quad(473 \mathrm{ml} / \text { acre })\end{array}$ & $5.50 \mathrm{ml}$ & $\begin{array}{l}\text { McLaughlin Gormley King Co., } \\
\text { Inc. Minneapolis, MN, USA }\end{array}$ \\
\hline $\begin{array}{l}\text { Grandevo }{ }^{\circledR} \mathrm{SC} \\
\text { (Furrow) }\end{array}$ & $\begin{array}{l}\text { Chromobacterium } \\
\text { subtsugae }\end{array}$ & $\begin{array}{l}1.36 \mathrm{~kg} / \text { acre } \\
(3 \mathrm{lbs} / \text { acre })\end{array}$ & - & $\begin{array}{l}\text { Marrone Bio Innovations Inc., } \\
\text { CA, USA }\end{array}$ \\
\hline $\begin{array}{l}\text { Venerate }^{(\mathbb{R}} \mathrm{XC} \\
\quad(\text { Seed treatment })\end{array}$ & $\begin{array}{l}\text { Heat killed Burkholderia } \\
\text { sp. srain A396 }\end{array}$ & $\begin{array}{l}0.41 \mathrm{ml} / 2.9 \mathrm{~g} \mathrm{seed} \\
\quad(384.46 \mathrm{ml} / \text { acre })\end{array}$ & - & $\begin{array}{l}\text { Marrone Bio Innovations Inc., } \\
\text { CA, USA }\end{array}$ \\
\hline $\begin{array}{l}\text { Venerate }{ }^{\mathbb{R}} \mathrm{XC} \\
\text { (Foliar treatment) }\end{array}$ & $\begin{array}{l}\text { Heat killed Burkholderia } \\
\text { sp. srain A396 }\end{array}$ & $\begin{array}{l}11.45 \mathrm{ml} / \mathrm{L} \\
(3784 \mathrm{ml} / \text { acre })\end{array}$ & $43.33 \mathrm{ml}$ & $\begin{array}{l}\text { Marrone Bio Innovations Inc., } \\
\text { CA, USA }\end{array}$ \\
\hline
\end{tabular}

\section{Data collection}

Prior to the application of treatments, each plot was rated for feeding injury by $P$. cruciferae along one 3.6$\mathrm{m}$ section of row, by sampling 10 plants at $0.3 \mathrm{~m}$ intervals before treatment applications (PT). Phyllotreta cruciferae injury measurements were made by visual examination of canola plants in each plot, on a 5-grade scale as defined in European and Mediterranean Plant Protection Organization (OEPP/EPPO 2004). The visual injury ratings were converted into percent leaf area injury, where $1=0 \% ; 2=2 \% ; 3=5 \% ; 4=10 \%$; and $5=$ $25 \%$ injury to the leaf area. Post-application ratings for P. cruciferae injury at 14 days after application of foliar insecticides (14 DPT) were used to determine the treatment efficacy duration. Treatment effects were evaluated by comparing feeding injury and yield.

The canola plots were straight combined at $30 \%$ seed moisture, stored and air dried at $7 \mathrm{~d}$ until the moisture content of seeds was $8-10 \%$. The seeds were then cleaned and weighed to determine the seed yield per plot and expressed as kilograms per hectare for each experimental unit.

Statistical analysis

Data were analyzed by performing analyses of variance (ANOVA) using PROC Mixed procedure for estimates of least square means and determining overall treatment effects (Type 3 test of fixed effects $F$-test) on $P$. cruciferae feeding injury ratings and yield (PROC Mixed, SAS Institute 2017). Treatments were considered as fixed while block was considered as random effect in this model. Bonferroni correction was applied for mean comparison tests. Therefore multiple comparison among the treatments were made using LSD mean separation test $\alpha=0.005$.

\section{Results}

Leaf area injury

Irrespective of treatment or location, the pre-treatment (PT) leaf area injury percentages were in the range of 1.7-5.3 (Table 2). This study clearly demonstrated that treatments have significant impact on $P$. cruciferae injury level at both locations: Conrad $(F=11.35$; $P<0.0001)$ and Sweetgrass $(F=21.83 ; P<0.0001)$. Significantly lower mean leaf area injury percentages ( \pm SEM) were observed among the treatments at the Conrad location for Gaucho ${ }^{\circledR}(7.60 \pm 0.7)$ and Entrust ${ }^{\circledR}$ $(8.50 \pm 0.6)$ followed by Venerate ${ }^{\circledR}$ foliar $(12.60 \pm 0.9)$ treatments than in untreated control $(16.00 \pm 0.6)$ (Table 2). Azadirect ${ }^{\circledR}$, Grandevo $^{\circledR}$ and Venerate ${ }^{\circledR}$ (seed 
Table 2 Crucifer flea beetle leaf area feeding injury (LS means estimates \pm SEM) to canola seedlings treated with biopesticides and chemical seed treatment in Montana

\begin{tabular}{|c|c|c|c|c|}
\hline \multirow[t]{2}{*}{ Treatment } & \multicolumn{2}{|l|}{ Conrad } & \multicolumn{2}{|c|}{ Sweetgrass } \\
\hline & $\mathrm{PT}^{\mathrm{a}}$ & $14 \mathrm{DPT}^{\mathrm{b}}$ & PT & $14 \mathrm{DPT}$ \\
\hline \multicolumn{5}{|l|}{ Leaf area injury (\%) } \\
\hline Water (Untreated control) & $3.8 \pm 0.2$ & $16.0 \pm 0.6 \mathrm{a}^{1}$ & $5.1 \pm 0.2$ & $21.4 \pm 0.5 \mathrm{a}$ \\
\hline Gaucho $^{\circledR} 600$ (Chem. check) & $1.7 \pm 0.3$ & $7.63 \pm 0.7 \mathrm{c}$ & $3.1 \pm 0.3$ & $8.00 \pm 0.4 \mathrm{e}$ \\
\hline Entrust $^{{ }^{\mathbb{R}}}$ & $4.3 \pm 0.4$ & $8.50 \pm 0.6 \mathrm{c}$ & $4.8 \pm 0.4$ & $14.5 \pm 0.8 \mathrm{~cd}$ \\
\hline Steinernema feltiae + Barricade ${ }^{\circledR}$ & $4.6 \pm 0.5$ & $13.4 \pm 1.0 \mathrm{ab}$ & $4.9 \pm 0.4$ & $11.8 \pm 0.6 \mathrm{~d}$ \\
\hline Aza-Direct ${ }^{\circledR}$ & $3.9 \pm 0.4$ & $16.4 \pm 1.2 \mathrm{a}$ & $5.1 \pm 0.4$ & $16.3 \pm 0.9 \mathrm{bc}$ \\
\hline PyGanic $1.4^{\circledR}$ EC & $3.9 \pm 0.4$ & $15.3 \pm 1.1 \mathrm{ab}$ & $4.4 \pm 0.4$ & $16.0 \pm 0.8 \mathrm{bc}$ \\
\hline Grandevo $^{\circledR} \mathrm{SC}$ & $4.6 \pm 0.5$ & $14.1 \pm 1.1 \mathrm{ab}$ & $5.2 \pm 0.2$ & $19.0 \pm 0.8 \mathrm{ab}$ \\
\hline Venerate ${ }^{\mathbb{R}}$ XC- Seed & $3.9 \pm 0.4$ & $14.1 \pm 1.1 \mathrm{ab}$ & $5.2 \pm 0.2$ & $17.4 \pm 0.9 \mathrm{bc}$ \\
\hline Venerate $^{\circledR}$ XC- Foliar & $4.3 \pm 0.4$ & $12.6 \pm 0.9 \mathrm{~b}$ & $5.3 \pm 0.3$ & $16.0 \pm 0.8 \mathrm{bc}$ \\
\hline$F ; P$ value & - & $11.35 ;<0.0001$ & - & $21.83(<0.0001)$ \\
\hline
\end{tabular}

$\mathrm{a}$ and $\mathrm{b}$ Injury ratings pre foliar and 14 days after foliar application, respectively

${ }^{1}$ Mean differences among the treatments are based on LSD (0.005)

treatment) were not significantly different from the untreated control.

At the Sweetgrass location, three treatments, Gaucho $^{\circledR}(8.00 \pm 0.4)$ followed by S. feltiae $(11.80 \pm 0.6)$ and Entrust ${ }^{\circledR}(14.50 \pm 0.8)$ had significantly lower mean leaf area injury percentage ( \pm SEM) as compared to untreated control $(21.40 \pm 0.5)$.

\section{Canola seed yield}

Average canola seed yield ranged from 486 to $1094 \mathrm{~kg} / \mathrm{ha}$ and from 1381 to $1611 \mathrm{~kg} / \mathrm{ha}$ respectively, at the Conrad and Sweetgrass locations (Fig. 2). Treatments showed significant impact on canola seed yield at Conrad $(F=$ 4.21; $P=0.002)$ but only marginally at Sweetgrass $(F=$ $2.20 P=0.11)$. At Conrad, seed yields in the Gaucho ${ }^{\circledR}$ $(1093.5 \pm 68.1)$ followed by Entrust ${ }^{\circledR}(863.0 \pm 68.8)$ and $S$. feltiae $(817.2 \pm 65.0)$ treated plots had higher yields than untreated control $(631.50 \pm 50.4 \mathrm{~kg} / \mathrm{ha})$. However, only Gaucho ${ }^{\circledR}$ treatment was significantly higher $(P<0.05)$ than the untreated control. At the Sweetgrass location, canola seed yields in the $S$. feltiae $(1611 \pm 76.3)$ and Gaucho ${ }^{\circledR}(1592 \pm 127.8)$ treatments had significantly higher yields than untreated control $(1381 \pm 57.9 \mathrm{~kg} / \mathrm{ha})$. Entrust $^{\mathbb{}}{ }^{\text {, Aza-Direct }}{ }^{\circledR}$, Grandevo ${ }^{\circledR}$ and Venerate ${ }^{\mathbb{R}}$ treatments had only numerically higher canola seed yields than the untreated control.

\section{Discussion}

Development of eco-friendly insect pest control systems for the P. cruciferae is important because of environmental concerns and resistance development due to continuous applications of synthetic insecticides like imidacloprid (Knodel 2017). This study tested the performance of several commercially available biopesticides for $P$. cruciferae management based on canola leaf area injury ratings and seed yield levels, under dryland farming system of Montana. This study showed that the foliar applications of biopesticides including Entrust ${ }^{\circledR}$, S. feltiae + Barricade ${ }^{\circledR}$ and Venerate ${ }^{\circledR}$ could be valuable treatments for $P$. cruciferae management when compared with untreated control, despite the variability of the products performance. Performances of these potential biopesticide were comparable to synthetic chemical seed treatment Gaucho ${ }^{\circledR}$, which is most commonly used in Montana for flea beetle management (Reddy et al. 2014; Antwi and Reddy 2016).

Irrespective of the location, this study clearly demonstrated that Entrust ${ }^{\circledR}$ was able to maintain low leaf area injury ratings of 8.5 and $14.5 \%$ when compared to untreated control which were 16.0 and $21.4 \%$ at Conrad and Sweetgrass, respectively. Considering the variability in weather, and consistency in effects of Entrust ${ }^{\circledR}$ between locations, we can speculate that this product may perform well under high range of temperature differences. 
Fig. 2 Effect of biopesticides $($ mean $\pm \mathrm{SE})$ on canola seed yield ( $\mathrm{kg} / \mathrm{ha})$ at two field locations (Conrad and Sweetgrass) in Montana, 2016. Bar bearing the same upper or lower-case letters are not significantly different. Mean comparisons were followed by Bonferroni correction LSD test, $\alpha=0.005$

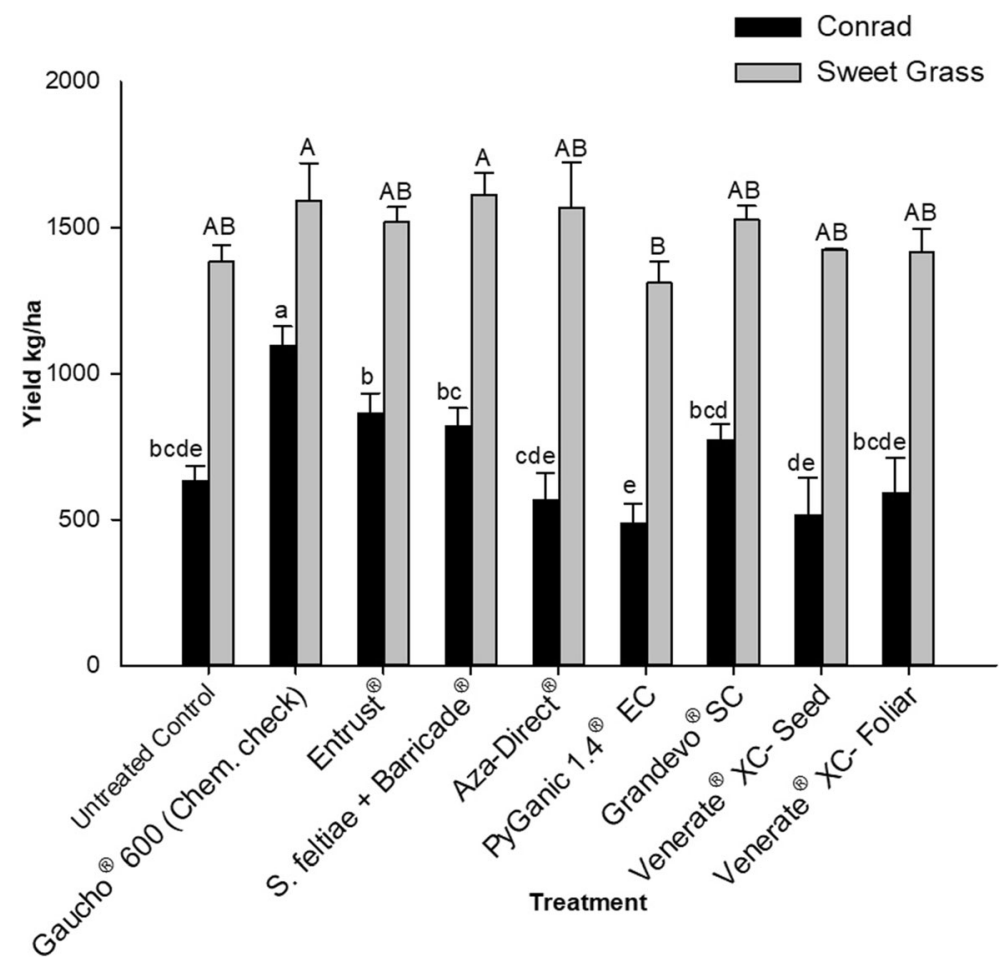

Previously, in a laboratory experiment, Elliott et al. (2007) found that the treatment efficacy was temperature dependent as Entrust was more effective at $25{ }^{\circ} \mathrm{C}$ than $15{ }^{\circ} \mathrm{C}$ in causing P. cruciferae mortality. However, the results of the present study were in agreement with Fang and Subramanyam (2003) observations, who reported that the toxicity of Entrust to the Rhyzopertha dominica F. (Coleoptera: Bostrichidae) was not temperature related. Similar to our observations, previous studies have found that Entrust ${ }^{\circledR}$ was effective biopesticide than other products including neem (azadirachtin) and fungal entomopathogen $B$. bassiana in terms of suppressing flea beetle injury in field conditions (Antwi et al. 2007a, b). Based on our results along with other findings, it warrants that Entrust ${ }^{\circledR}$ product needs to be tested further across multiple locations and validated.

Application of entomopathogenic nematode (EPN) S. feltiae with $1 \%$ Barricade ${ }^{\circledR}$ polymer gel maintained significantly lower feeding pressure of $P$. cruciferae compared to the untreated control at Sweetgrass but same was not observed at the Conrad location. Preferred and ubiquitous environment for the EPNs is the soil (Gaugler 1988; Kaya 1990; Hominick et al. 1996), whereas above ground application of nematodes would provide conditions atypical for nematode activity and survival primarily due to moisture constraints on the crop foliage (Arthurs et al. 2004). Shapiro-Ilan et al. (2010, 2016) observed that addition of sprayable polymer gel (1-3\%) was helpful in protecting EPNs from adverse conditions such as desiccation and ultraviolet radiations. The field experiments conducted by Antwi and Reddy (2016) have found that when sprayable polymer gel (Barricade ${ }^{\mathbb{R}}$ polymer $1 \%$ ) was added to the $S$. feltiae, their efficacy was at par with imidacloprid $\left(\right.$ Gaucho $\left.{ }^{\circledR}\right)$ chemical seed treatment. Considerable variation between the locations in terms of weather conditions may be one of the possible explanations for the differences among the sites regarding EPNs (Steinernema feltiae + Barricade ${ }^{\circledR}$ ) performance. Low level of precipitation leading to low moisture at the time of application, may have contributed to their low efficacy at the Conrad location. Therefore, further investigations is needed for finding better drought tolerant EPN strains, besides being highly pathogenic, under West-Central Montana conditions.

At both locations, plant derived products including Aza-Direct ${ }^{\circledR}$ and Pyganic $1.4^{\circledR}$ EC did not reduce P. cruciferae feeding injury pressure when compared to the untreated control. Aza-Direct ${ }^{\mathbb{R}}$ (Azadirachtin) is derived from the seeds of Azadirachta indica (Meliaceae), and is reported to have repellent or 
insecticidal activity against $P$. cruciferae (Boopathi et al. 2010). Specific to Montana, Reddy et al. (2014) observed that neem showed some effect only either with repeated spray applications or with mixing with fatty acids on canola. Similarly multiple applications of pyrethrins (Pyganic 1.4 ${ }^{\circledR}$ EC) derived from the extracts of chrysanthemum flowers, were reported to provide significant reduction in the population of potato leaf hoppers, Empoasca fabae Harris (Hemiptera: Cicadellidae) (Maletta et al. 2006). It appears that repeated foliar sprays are probably needed for keeping acceptable control especially if hot and dry conditions prevail for a longer period of time, as observed in the current study.

Biopesticide products-Grandevo applied in furrows and Venerate applied as seed treatment, were least effective in managing the $P$. cruciferae feeding injury at both study locations. Both these products were also found to be ineffective against other insect pests including Swede midge, Contarinia nasturtii Kieffer (Diptera: Cecidomyiidae) and diamondback moth, Plutella xylostella L. (Lepidoptera: Plutellidae) under organic vegetable production (Seaman et al. 2015). Although, Grandevo ${ }^{\circledR}$ and Venerate ${ }^{\circledR}$ possess multiple modes of action as per the labels, their application as seed treatments could have exposed them to other resident soil microorganisms that exhibit antagonist effects (Jackson 1999). However, foliar application of Venerate treatment managed to maintain low P. cruciferae feeding injury at the Conrad location. To our knowledge, this is the first time that these products were explored for their potential to manage $P$. cruciferae in this region of Montana.

In summary foliar application of Entrust ${ }^{\mathbb{R}}$ was most effective in reducing $P$. cruciferae injury ratings at both the locations thereby, suggesting that this product may perform well within the high range of temperature differences under field conditions. In contrast the effects of EPNs Steinernema feltiae + Barricade $^{\circledR}$ and Venerate ${ }^{\circledR}$ $\mathrm{XC}$ likely differed due to the differences in weather parameters between the study locations. Although, there was no clear trend of yield increase, these treatments maintained numerically higher yield levels as compared to the untreated control. Further studies will be focused on the economics of the cost versus benefit of the effective treatments.

Acknowledgements This material is based upon work that is supported by the National Institute of Food and Agriculture, U.S. Department of Agriculture, Multistate Project S-1052, and the Working Group on Improving Microbial Control of Arthropod Pests Covering Research in Montana under Accession \# 232056.
We would also like to thank John Miller, Amber Ferda and Julie Prewett for assistance with field work.

\section{Compliance with ethical standards}

Conflict of interest The authors disclose no potential conflicts of interest associated with this manuscript.

\section{References}

Alberta Agriculture and Forestry (2016). Weather report; Available from: https://agriculture.alberta.ca/acis/townshipdata-viewer.jsp. Cited 15 Nov 2017.

Antwi, F. B., \& Reddy, G. V. P. (2016). Efficacy of entomopathogenic nematodes and sprayable polymer gel against crucifer flea beetle (Coleoptera: Chrysomelidae) on canola. Journal of Economic Entomology, 109, 1706-1712.

Antwi, F., Olson, D., \& Knodel, J. (2007a). Comparative evaluation and economic potential of ecorational versus chemical insecticides for crucifer flea beetle (Coleoptera: Chrysomelidae) management in canola. Journal of Economic Entomology, 100, 710-716.

Antwi, F., Olson, D., \& Carey, D. (2007b). Comparisons of ecorational and chemical insecticides against crucifer flea beetle (Coleoptera: Chrysomelidae) on canola. Journal of Economic Entomology, 100, 1201-1209.

Arthurs, S., Heinz, K., \& Prasifka, J. (2004). An analysis of using entomopathogenic nematodes against above-ground pests. Bulletin of Entomological Research, 94, 297-306.

Boopathi, T., Pathak, K. A., Ngachan, S., \& Nabajyoti, D. (2010). Evaluation of neem oil and insecticides against Phyllotreta cruciferae on broccoli. Annals of Plant Protection Science, $18,236-237$.

Burgess, L. (1977). Flea beetles (Coleopetra: Chrysomelidae) attacking rape cropsin the Canadian prairie provinces. The Canadian Entomologist, 109, 21-32.

Copping, L. G., \& Menn, J. J. (2000). Biopesticides: a review of their action, applications and efficacy. Pest Management Science, 56, 651-676.

Elliott, R. H., Benjamin, M. C., \& Gillott, C. (2007). Laboratory studies of the toxicity of spinosad and deltamethrin to Phyllotreta cruciferae (Coleoptera: Chrysomelidae). The Canadian Entomologist, 139, 534-544.

Fang, L., \& Subramanyam, B. (2003). Activity of spinosad against adults of Rhyzopertha dominica (F.) (Coleoptera: Bostrichidae) is not affected by wheat temperature and moisture. Journal of the Kansas Entomological Society, 76, 529-532.

Gaugler, R. (1988). Ecological considerations in the biological control of soil-inhabiting insects with entomopathogenic nematodes. Agriculture, Ecosystems and Environment, 24, 351-360.

Hajek, A. E., Soper, R. S., Roberts, D. W., Anderson, T. E., Biever, K. D., Ferro, D. N., Leburn, R. A., \& Storch, R. H. (1987). Foliar applications of Beauveria bassiana (Balsamo) for control of the Colorado potato beetle, Leptinotarsa decemllineata (Say) (Coleoptera, Chrysomelidae), an 
overview of pilot test results from the northern United States. The Canadian Entomologist, 119, 959-974.

Hominick, W. M., Reid, A. P., Bohan, D. A., \& Briscoe, B. R. (1996). Entomopathogenic nematodes: biodiversity, geographical distribution and the convention on biological diversity. Biocontrol Science and Technology, 6, 317-331.

Jackson, T. A. (1999). Factors in the success and failure of microbial controlagents for soil dwelling pests Integrated. Pest Management Reviews, 4, 281-285.

Kaya, H. K. (1990). Soil ecology. In R. Gaugler \& H. K. Kaya (Eds.), Entomopathogenic nematodes in biological control (pp. 93-115). Boca Raton: CRC Press.

Knodel, J. J. (2017). Flea Beetles (Phyllotreta spp.) and Their Management I. In G. V. P. Reddy (Ed.), Integrated Management of Insect Pests on Canola and Other Brassica Oilseed Crops (pp. 1-12). Oxfordshire: CABI.

Lamb, R. (1984). Effects of flea beetles, Phyllotreta spp.(Chrysomelidae: Coleoptera), on the survival, growth, seed yield and quality of canola, rape and yellow mustard. The Canadian Entomologist, 116, 269-280.

Lamb, R. (1988). Assessing the susceptibility of crucifer seedlings to flea beetle (Phyllotreta spp.) damage. Canadian Journal of Plant Science, 68, 85-93.

Lamb, R., \& Turnock, W. (1982). Economics of insecticidal control of flea beetles (Coleoptera: Chrysomelidae) attacking rape in Canada. The Canadian Entomologist, 114, 827-840.

Liu, T. X., \& Stansly, P. A. (1995). Toxicity and repellency of some biorational insecticides to Bemisia argentifolii on tomato plants Entomologia. Experimentalis et Applicata, 74, 137-143.

Madder, D., \& Stemeroff, M. (1988). The economics of insect control on wheat, corn, and canola in Canada, 1980-1985 The economics of insect control on wheat, corn, and canola in Canada, 1980-1985. Bulletin of Entomological Society of Canada, 20, 1-22.

Maletta, M., Henninger, M., \& Holmstrom, K. (2006). Potato leafhopper control and plastic mulch culture in organic potato production. HortTechnology, 16, 199-204.

NRCS (2016) United States Department of Agriculture Natural Resources Conservation Service. Weather report; Available from: https://wcc.sc.egov.usda.gov/nwcc/site?sitenum=2117. Cited 15 Nov 2017.

OEPP/EPPO (2004) Efficacy evaluation of insecticides. Phyllotreta spp. On rape, pp. 242-244. OEPP/EPPO Bull. Pp 1/218.

Reddy, G. V. P., Tangtrakulwanich, K., Wu, S., Miller, J. H., Ophus, V. L., \& Prewett, J. (2014). Sustainable management tactics for control of Phyllotreta cruciferae (Coleoptera: Chrysomelidae) on canola in Montana. Journal of Economic Entomology, 107, 661-666.
SAS Institute Inc. (2017). 9.4 In-Database Products, User's Guide (5th ed.). Cary: SAS Publishers.

Seaman, A. J., Lange, H. W., \& Shelton, A. M. (2015). Swede midge, Diamondback moth, and imported cabbageworm control with insecticides allowed for organic production, 2014. Arthropod Management Tests, 40, E48. https://doi. org/10.1093/amt/tsv104.

Shapiro-Ilan, D. I., Cottrell, T. E., Mizell, R. F., Horton, D. L., Behle, R. W., \& Dunlap, C. A. (2010). Efficacy of Steinernema carpocapsae for control of the lesser peachtree borer, Synanthedon pictipes: Improved aboveground suppression with a novel gel application. Biological Control, $54,23-28$.

Shapiro-Ilan, D. I., Cottrell, T. E., Mizell, R. F., \& Horton, D. L. (2016). Efficacy of Steinernema carpocapsae plus fire gel applied as a single spray for control of the lesser peachtree borer, Synanthedon pictipes. Biological Control, 94, 33-36.

Shrestha, G., \& Reddy, G. V. P. (2017). Field efficacy of insect pathogen, botanical and jasmonic acid for the management of wheat midge Sitodiplosis mosellana and the impact on adult parasitoid Macroglenes penetrans populations in spring wheat. Insect Sci. https://doi.org/10.1111/1744-7917.12548.

Shrestha, G., Enkegaard, A., \& Steenberg, T. (2015). Laboratory and semi-field evaluation of Beauveria bassiana (Ascomycota: Hypocreales) against the lettuce aphid, Nasonovia ribisnigri (Hemiptera: Aphididae). Biological Control, 85, 37-45.

Soroka, J., Grenkow, L., Otani, J., Gavloski, J., \& Olfert, O. (2018). Flea beetle (Coleoptera: Chrysomelidae) species in canola (Brassicaceae) on the northern Great Plains of North America. The Canadian Entomologist, 150, 1-16.

Sparks, T. C., Crouse, G. D., \& Durst, G. (2001). Natural products as insecticides: the biology, biochemistry and quantitative structure-activity relationships of spinosyns and spinosoids. Pest Management Science, 57, 896-905.

Thomas, P. (2003). Canola growers manual. Winnipeg: Canola Council of Canada.

Thompson, G. D., Dutton, R., \& Sparks, T. C. (2000). Spinosad- a case study: an example from a natural products discovery programme. Pest Management Science, 56, 696-702.

Turnock, W., \& Turnbull, S. (1994). The development of resistance to insecticides by the crucifer flea beetle, Phyllotreta cruciferae (Goeze). The Canadian Entomologist, 126, 1369-1375.

Ware, G. W. (1989). The pesticide book (3rd ed.). Fresno: Thompson Publications.

Xu, C., Clercq, P. D., Moens, M., Chen, S., \& Han, R. (2010). Efficacy of entomopathogenic nematodes (Rhabditida: Sternenematidae and Heterorhabditidae) against the striped flea beetle, Phyllotreta striolata. BioControl, 55, 789-797. 